\title{
REDD+ policy networks in Brazil: constraints and opportunities for successful policy making
}

\author{
Maria Fernanda Gebara ${ }^{1,2,3}, \underline{\text { Leandra Fatorelli }}^{4}$, Peter Mav ${ }^{1,2}$ and Shaozeng Zhang $^{5}$
}

\begin{abstract}
The prospective introduction of REDD+ (Reducing Emissions from Deforestation and forest Degradation and enhancement of carbon stocks) in Brazil has generated many questions about its form of implementation and likely environmental effectiveness. These issues must be addressed to reduce the risks associated with REDD+, such as conflicts over land and forest resources, and increase the likelihood of successful outcomes, as equitable benefits sharing. In this study, we examine how policy actors such as NGOs, government, and the private sector influence the REDD+ policy process in Brazil. We analyze actors' positions on key issues in REDD+ (conflicts; benefits sharing; free, prior, and informed consent; tenure; and coordination) to identify associated constraints and opportunities for REDD+ policy making with a focus on the national strategy. We examine the structure of three policy networks in this policy arena (prestige, information exchange, and collaboration) with the aim of explaining these constraints and opportunities, so that policy can be positively modified or adapted ahead of its implementation. We note that the presence of polarization on the issues analyzed implies the need for better negotiation among actors if REDD+ is to move forward effectively. Furthermore, the absence of coordination between types of actors (private sector, government, and NGOs) suggests that achieving optimal REDD+ governance in Brazil will be difficult. Finally, we propose some directions for REDD+ policy making in Brazil that could help policy managers and stakeholders improve the design and implementation of the national strategy.
\end{abstract}

Key Words: actors; Brazil; networks; policy making; REDD+

\section{INTRODUCTION}

REDD+, or reducing emissions from deforestation and forest degradation and enhancement of carbon stocks, emerged in 2007 as an instrument proposed for mitigating climate change by financially rewarding tropical countries for preserving their standing forests (IPCC 2007, Stern 2007, UNFCCC 2007, Eliasch 2008). The Cancun Agreements (UNFCCC 2010) define REDD+ as encompassing emission reductions and as seeking to halt and reverse forest loss. Furthermore, the agreements encourage all countries to find effective ways to reduce forest-related human activities that cause greenhouse gas (GHG) emissions. To comply, countries are urged to adopt public policies to remove drivers of deforestation both through incentives for good land-use practices, such as sustainable forest management, and through removal of harmful subsidies, such as low-interest credit for extensive cattle ranching. The prospective introduction of such policy instruments as part of a REDD+ strategy in the Brazilian forest management and land-use regulation has generated many questions about their form of implementation and their potential effectiveness.

In this study, we examine how policy actors such as NGOs, government, and the private sector influence REDD+ policy making in Brazil. We emphasize a combination of network analysis and actors' discourse to investigate how actors bring their influence to design the Brazilian national REDD+ strategy, still in formulation. We analyze actors' "stances," that is, their positions on statements, on key REDD+ issues to identify the associated constraints and opportunities for REDD+ policy making. We examine multiple social network measures of policy actors' influence to assess which actors are prominent in influencing REDD+ policy design. We assume that a successful outcome will be more likely if constraints that could arise during policy implementation are considered at the policy design stage. In this paper, the policy design stage corresponds to the construction of the Brazilian national strategy on REDD+. We measure if it is likely to be a successful outcome by exploring how different actors may have influenced this process and how the strategy considers the constraints pointed out by actors.

Our main research questions are:

1. Which policy actors are active in the policy networks that influence REDD+ policy making?

2. How do policy actors in Brazil differ in their stances on REDD+ issues?

3. What are the constraints and opportunities for successful REDD+ policy design in Brazil?

We broadly define the concept "policy network" as a structure formed by state and nonstate actors, their attributes, and the relations among them. We conceive of policy networks as a body of theory, which can explain policy dynamics and outcomes (Carlsson 2000, Besussi 2006), anchored in the social network analysis approach. We use this approach to analyze characteristics of the policy-making process around REDD + . Social relational approaches such as policy network analysis and related sociopolitical theories are helpful for understanding governance processes and outcomes through integrated analysis of the design of social networks and policy actors' characteristics (Bodin and Prell 2011).

Our main hypothesis is that central actors in policy networks may be able to guarantee adherence, thereby making their stances with regard to REDD+ dominant in the national strategy. A secondary hypothesis, related to the first, is that policy networks and policy actors who represent different sectors in Brazil have discordant interests regarding REDD+. This difference may reflect and affect opportunities and constraints for effective policy making, which would in turn shape the design and outcomes of the REDD+

${ }^{1}$ Federal Rural University of Rio de Janeiro, ${ }^{2}$ Center for International Forestry Research, ${ }^{3}$ Department of International Development, LSE,

${ }^{4}$ Sustainability Research Institute, University of Leeds, ${ }^{5}$ University of California 
national strategy. Such opportunities and constraints may be related to coordination, consensus building, coalitions, conflicts, participation, and cohesion, among others (Newig et al. 2010).

\section{POLICY NETWORKS, NATURAL RESOURCE GOVERNANCE AND THE BRAZILIAN CONTEXT}

\section{Policy networks and natural resource governance}

Governance is no longer understood as hierarchical, top-down decision making, but rather as the interaction of actors in networks for policy making (Börzel 1998, Börzel and HeardLauréote 2009). Policy networks have become the focus of governance studies and related policy analysis, including that for policy on common pool resources and natural resource governance (Bodin and Prell 2011, Agrawal et al. 2012). This literature also considers the cross-scale nature, e.g., in space and time, of natural resources institutions (Berkes 2006, Brondizio et al. 2009, Ostrom 2009). Ideal strategies of governance involve dialogue among stakeholders and diversification of institutions, in terms of their types and multilevel arrangements, to support their adaptability to solve problems in complex social-ecological systems (Dietz et al. 2003). Such problems might include differences in socioeconomic contexts, local impacts, common property and others, all of which are relevant to REDD+ initiatives and policies (Dietz et al. 2003).

The approach of typologies of networks, associated with political process, was developed by Marsh and Rhodes (1992). According to this approach, policy outcomes could be guided in a certain direction depending on the type of policy networks involved. These referred primarily to policy community and issue networks. Two main schools of policy networks evolved in parallel seeking to explain the policy process. One school conceives "policy network" as an intermediation of interests and the other sees it as a mode of governance (Besussi 2006, Dassen 2010, Fawcett and Daugbjerg 2012). Besides these differences, both schools acknowledge the interdependence of actors and their resources as an important characteristic of a policy network, as well as defending the basic assumption that policy networks affect policy outcomes.

Social relations are a key factor underlying actors' behavior in facilitating or constraining policy actions and thereby also the development of management and governance institutions critical to REDD+ achievements (Bodin and Prell 2011). The relational approach embedded in policy network analysis elucidates the social dynamics that shape natural resource governance, through a combined analysis of social networks, social theories, and related social or ecological variables pertinent to the issue of interest (Bodin and Prell 2011). This approach is useful for understanding political relations among stakeholders, allowing us to verify the existence of barriers or opportunities to knowledge sharing and for the creation of learning, collaboration, and coordination environments essential for effective natural resource governance and policy (Bodin and Prell 2011). Such conditions are critical to successful REDD+ policy design and implementation.

In the field of natural resource governance studies, three main research domains have been developed using relational approaches. As discussed by Bodin and Prell (2011), the first domain refers to work on outcomes in natural resource governance, such as biophysical variables and public policy achievements (see, for example, work by Cumming et al. 2010, Newig et al. 2010, and Sandström 2011). The second domain encompasses research on the features of network governance and their contexts, from a network structure perspective (Newman and Dale 2005, Bodin et al. 2006, Janssen et al. 2006, Bodin and Crona 2009). The third area of research reveals potentially influential actors and their roles in political processes (Prell et al. 2009, Reed et al. 2009, Bodin and Prell 2011, Ernstson 2011, Prell 2011). In relation to the latter, some authors consider policy networks as "power dependency relationships between government and interest groups, in which resources are exchanged" (Börzel 1998:256). Policy networks then reflect the relative status or power of particular interests (Börzel 1998), where power is central and can be defined as the "ability to influence the decisions or actions of others" (Thorelli 1986:38). In the current research we combine the third relational approach with the first one.

We investigate actors' influence in policy networks through two network dimensions: perceived influence, referring to the reputational power an actor has according to other actors in the network (Kriesi et al. 2006, Fischer et al. 2009, Brockhaus et al. 2013), and relational influence, referring to the actors' central positions in information exchanges and collaboration networks. We use multiple social network analysis measures of influence of policy actors to assess their prominence and impact in policy making outcomes, more specifically in the design process of the Brazilian REDD+ national strategy.

\section{The Brazilian context}

Under Brazil's 1988 Constitution (Article 1), the federal government, states, municipalities, and federal districts share the authority to legislate on several issues related to natural resources, including forest conservation. In general, the federal government establishes the norm and the states and federal districts may adopt more specific regulations. Despite this, REDD+ policy making at the national level emerged first in response to a global concern. The United Nations Framework Convention on Climate Change (UNFCCC) negotiations foresaw some broad brush features in REDD+ implementation architectures, but left it up to the different national parties to create appropriate political and institutional models for the implementation of REDD+ initiatives on the ground (Angelsen et al. 2009).

The Working Group on Long-Term Cooperative Action under the 16th Conference of the Parties on Climate Change, COP16, encouraged developing country parties to contribute to emissions reductions from deforestation (UNFCCC 2010). According to the Working Group's deliberations, these actions should be undertaken in tiers, starting with the development of a national strategy or action plan (UNFCCC 2010). National strategies were seen not only as a commitment to reduce GHG emissions, but they should address, at a minimum, the "drivers of deforestation and forest degradation, land tenure issues, forest governance issues, gender considerations and the safeguards" (UNFCCC 2010:11). Discussion regarding development of the REDD+ strategy should be coordinated by the host country and accomplished with full and effective participation of relevant stakeholders, including indigenous peoples and local communities (UNFCCC 2010). 
In Brazil, the Interministerial Working Group on REDD+, a high level policy group, is working to negotiate and build the national strategy based on the discussion of four main points: financial architecture, technical aspects, governance arrangements and investments, and positive economic incentives. Three different working groups (WG) operated during 2010 to discuss these points, involving participants from governmental, nongovernmental, civil society, and private sector organizations. They specifically addressed: (i) coordination, institutional arrangements, and participation; (ii) benefit distribution, property rights, and safeguards; and (iii) sources of resources and funding mechanisms. In addition, the Department of Climate Change and Environmental Quality of the Ministry of Environment formed a panel of experts composed of actors from different sectors to provide input on issues relating to financing and benefits sharing. Results of the consultations carried out by WGs, experts, and high level panels are being incorporated in the strategy document to be launched by the end of 2014. Before that, the Interministerial Working Group will analyze the suggestions made in the public consultation as the basis for final review and approval of the national strategy.

In addition, some ministries, under the leadership of the Office of the Presidential Chief of Staff, along with state governments of the Amazon region formed the States' Task Force in 2012, to promote a dialogue process between federal and states governments, to negotiate key aspects of REDD+ projects and programs being implemented at the subnational level. Finally, a Multisectoral Committee was created by civil society in 2010 to elaborate socio-environmental principles and criteria for acceptable REDD+ initiatives. The Multisectoral Committee included 21 organizations, most from the organized civil society sector, and none from the government sector with contributions of indigenous and traditional people. This process resulted in a document on Developing social and environmental safeguards for REDD+: a guide for a bottom-up approach (Bonfante et al. 2010; authors' translation). Even with all these initiatives, most of which occurred in 2010, a policy vacuum persisted at the federal level. The absence of a national REDD+ strategy led states, nonstate actors, and private enterprises to engage in local pilot initiatives in an effort to "jump start" REDD+ as a way to show the way forward.

As explained above, we seek in this article to explore possible policy constraints and opportunities for REDD+ in Brazil by identifying how networks are structured and how they influence the policy design of the national strategy. Our use of policy network analysis to explore possible policy constraints and opportunities is supported by two central features of REDD+ governance in Brazil: the country's federal system, which creates a need for cross-sectoral and multilayered coordination and collaboration, and the nature of forest governance as a complex social-ecological system (May et al. 2011a). Brazil is an extraordinarily "differentiated polity" (Rhodes 1997). Policy sectors, such as forestry or land use policy, have very different decision rules and dominant actors (May et al. 2011a). Furthermore, policy makers do not routinely engage in crosssectoral collaboration, which provokes policy battles in which impenetrable barriers are placed around policies in a given sector so that they cannot be altered or undone by actors with conflicting sectoral interests (Gebara et al. 2012). For example, mainstream development policies for the Brazilian Amazon, such as the Program for Accelerated Growth, tend to be inconsistent with policies to relieve deforestation pressures.

Lack of coordination, institutional fragmentation, and dichotomies of "development vs. environment" abound, particularly in the electrical energy, transportation, and agribusiness sectors (May et al. 2011a). One possible consequence is a tendency for policy networks built around specific policy issues to be discrete, distinct, and largely disconnected from one another, even when they preside over policies that are clearly connected. For example, policies in both the agriculture and the forestry sectors influence key areas such as economic development and environmental protection. Most sectors have diverse memberships, extending to public and private, political and administrative, and national, international, and subnational actors. Policy network and stances analysis can therefore help us to reveal the tendencies in policy making relevant to the REDD+ policy arena in Brazil.

\section{METHODS}

\section{Study boundaries}

The REDD+ policy arena is characterized by social and ecological dimensions such as those associated with communitybased forest management and the emergence of multiscale governance institutions (Cronkleton et al. 2011). Given the pioneering nature of this research, our starting point was to define the REDD+ socio-political boundaries, that is, the institutions and actors involved in issues related to REDD+. To do this, we used expert consultations informed by a country profile and a systematic review of REDD+ in the Brazilian media (May et al. $2011 a, b$ ), which were completed as part of a global comparative study on REDD+ policies and processes; we followed the methodologies and the research design outlined in Brockhaus and Di Gregorio (2012).

In seeking to identify the main actors in the REDD+ arena whose roles have impacts across levels, we took into account the various scales of political boundaries, such as levels of governance, and ecosystem boundaries, namely types of biomes, as defined at the country level. Although REDD+ networks presumably involve all major forest biomes, in practice, REDD+ policy networks revolve around the Brazilian Amazon, as a focus of global concern over deforestation, and the source of most of Brazil's GHG emissions associated with land use change. Policy networks related to the Amazon biome are therefore the focus of this paper.

\section{Research approach}

The field research was carried out from June 2010 to September 2011. Following consultation with selected experts, we identified and contacted 65 organizations for interviews. Of these, 56 completed the full questionnaire, which served as the basis for our network analyses, discussed here. Some of the remaining nine organizations provided incomplete survey answers or semistructured interview responses. No organizations beyond the 65 initially identified were interviewed for or included in the following analyses. A list of the organizations surveyed is given in the Appendix to this paper. For the data analyses in this study, we created six organizational categories: government $(n=19)$, private sector (4), national NGOs (15), national research institutions (6), international NGOs (8), and donors (4). 
The research was conducted with institutional representatives using quantitative and qualitative research instruments. The quantitative research comprised two parts: stances and networks. The stances analysis focused on key topics related to REDD+ implementation. In this paper, we examine stances related to the distribution of REDD+ benefits, land conflicts, and challenges for REDD+ implementation. Actors were queried regarding their agreement with three stance statements:

- REDD+ is an effective option for reducing GHG emissions globally;

- REDD+ benefits should go to large-scale industries for reducing forest emissions;

- REDD+ schemes will exacerbate conflicts over forestland and forest resources.

Although an analysis of a longer list of stances might be more informative in principle (for example, Sabatier and Jenkens-Smith 1993), the above three stances were selected because of their high relevance to the achievement of positive outcomes from REDD+ in Brazil (see, for example, MMA 2012).

The second strand of quantitative research analyzed the perceived and relational influence of the 56 actors who answered the network part of the questionnaires. Interviewees were asked to name from the list of 65 those actors that had, in their view, substantial influence on the national REDD+ regime, and with which they regularly exchanged information, and those with which they regularly collaborated. Based on their responses, we assessed the perceived influence of policy actors and their influence based on information exchanges, and collaboration linkages (relational influence). We used these networks to identify the most influential actors in the policy making process of the Brazilian REDD+ national strategy. Data analyses excluded the nine actors for which we lacked complete survey results.

Semistructured interviews were conducted as supplementary data to triangulate and verify the actors' roles. These interviews provided more depth and detail on the main stances and the preferred policy options of each organization. The semistructured interviews covered four topics: beliefs and interests; main challenges posed by REDD+; governance and consultation processes; and policy directions in terms of effectiveness, cost efficiency, equity, and other cobenefits. The analysis of these data focused on benefits sharing, equity, effectiveness, and challenges of REDD+ implementation because these topics proved controversial and were thus useful for identifying opportunities and constraints. These topics also feature in the national strategy under debate within the Ministry of Environment and among network actors and therefore are highly relevant to the performance of REDD+ in Brazil (MMA 2012).

\section{Data analysis}

To analyze the actors' stances, we compiled answers into categories of "agree" (includes "strongly agree"), "disagree" (includes "strongly disagree"), and "neither agree nor disagree" and analyzed responses to identify the main challenges for the national REDD+ strategy and hence REDD+ implementation.
To measure the extent to which each stance favored or constrained a policy actor, we needed to see where and how each actor was positioned in the "perceived influence network," "information," and "collaboration" networks. To this end, we used social network analysis, in which the location and importance of an actor embedded in the network are fundamental values (Wasserman and Faust 1994, Knoke and Yang 2008). In this method, a set of social network concepts, known as centrality measures, are employed to analyze various aspects of the networks. Centrality measures identify prominent actors in a policy network, reflecting their visibility, that is, their high connectivity to other actors in the network (Knoke and Yang 2008). We used degree, in-degree, and betweenness as centrality measures of actors' position in their networks (Freeman 1979, Hanneman and Riddle 2005, Prell 2011). The centrality measures were obtained using UCINET Social Network Analysis software (Borgatti et al. 2002, Hanneman and Riddle 2005). Participants were asked to indicate:

- Those organizations that stand out as especially influential in domestic REDD+ policies. We called the resulting network the "perceived influence network";

- Those organizations with which their organization regularly or routinely discusses and exchanges information about national REDD+ policy matters. We named the resulting network the "information network";

- Those policy actors with whom their organization regularly collaborates concerning REDD+ related issues and politics. This final network was labeled the "collaboration network".

We investigated influence of policy actors according to two dimensions. The first was perceived influence. We operationalized this type of influence using the measure of indegree centrality of the perceived influence network. Degree centrality refers to the number of ties a node has to other nodes, and in the case of the network cited, it refers to the number of nominations received, i.e., the number of times a policy actor is cited as important by others actors. In-degree centrality refers to the number of one-way incoming ties (Freeman 1979, Wasserman and Faust 1994, Scott 2000). The interviewees identified those actors whom they recognized as strongly influential in terms of specific capabilities, such as decisionmaking eligibility, financial control, or technical excellence regarding acknowledged REDD+ issues, activities, and concerns. Differences in in-degree centrality reflect dispersion, i.e., the presence of central nodes in the network, and power inequality among actors (Knoke and Yang 2008).

The second dimension was relational influence, which we analyzed based on the information and collaboration networks. The measure used was degree centrality. For this measure we used undirected networks. In the information network we considered reciprocal relations when just one actor cited another, in the collaboration network we used reciprocity, i.e., when both actors cited each other, as indicator of a collaborative tie. This was justified on the basis that effective collaboration requires 
more reciprocity than information exchanges. Additional network measures betweenness and brokerage were calculated for the information and collaboration networks to further assess actors influence in the REDD+ arena. Betweenness centrality refers to the extent to which other actors lie on the shortest path between pairs of actors in the network and indicates a favorable position (Hanneman and Riddle 2005, Knoke and Yang 2008). Betweenness centrality is also interpreted as a type of brokerage (Burt 2005, Bodin et al. 2006, Crona et al. 2011), an indicator of the potential control that a particular actor exerts over information exchange or resource flows (Knoke and Yang 2008), which corresponds to an influential structural positional achieved through intermediation (Diani 2003). We also applied Gould and Fernandez (1989) brokerage indices to the directed information and collaboration networks, based on an algorithm included in the UCINET package (Borgatti et al. 2002), to analyze the integration of institutional variables (the diversity of organizational categories, defined as state, private, and civil society actors) and the betweenness measures. This approach enabled us to verify the brokerage role of main actors in the information and collaboration networks.

To investigate how different actors may have influenced the elaboration of the national strategy on REDD+, we used these two influence dimensions, perceived and relational, and compared the main actors that emerged from these networks with the cast of characters who participated in the formal REDD+ policy process. The institutional arrangements of the formal process included: the Interministerial Working Group on REDD+, the three Working Groups on REDD+ themes, the States' Collaborative Task Force, the Panel of Experts, and the Multisectoral Committee.

Before introducing the results we should present a reflection about the limitation of this study and how we addressed it. Social network analysis investigates interactions at one point in time (time of the survey) and this needs to be taken into account when interpreting the data. Also, the paper suggests that stances of policy actors, and in particular those of the most influential actors on REDD+ debates, as well as their positions in information and collaboration networks, impact the direction and progress of the national REDD+ strategy. However, we do not attempt to statistically model this relationship and therefore provide exploratory evidence of how discourse and network positions impact REDD+ policy outputs. The aim instead is to illustrate in some depth the different roles that specific influential actors have in the policy domain and how their opinions, their preferred policy options have impacted the national REDD+ strategy, and which challenges lie ahead given current networking patterns.

\section{RESULTS}

\section{Policy actors' positions on REDD+}

Understanding the stances and opinions of actors is fundamental to assess their role in each network and to identifying their preferred direction regarding REDD+ policy making. We found that although most actors agreed on the potential effectiveness of REDD+, the statements on benefits and conflicts were polarizing. Almost all $(93 \%)$ of the surveyed organizations were optimistic about the effectiveness of REDD+ as an option for reducing GHG emissions. However, interviewees expressed some concerns about the challenges of achieving effectiveness in REDD+ implementation in Brazil. Most policy actors believed that REDD+ effectiveness would require clearer national and international rules, especially for monitoring, verifying, and reporting and for benefits sharing, and penalties, particularly for countries that fail to achieve their reduction targets. Some actors stated that the tendency of most REDD+ proposals to focus on benefits for poor and traditional communities, rather than on agribusinesses and large landholders, would undermine their effectiveness. This view is important because deforestation in Brazil is considered primarily a direct or indirect result of frontier expansion by export-commodity industries, supported by major government infrastructure initiatives and economic incentives (Assunção et al. 2013, Hargrave and Kis Katos 2013).

The topic of benefits sharing is very controversial in Brazil (Gebara 2011), and the national government has not expressed a clear position on this matter. Our findings exemplify the controversy surrounding REDD+ benefits sharing in Brazil: 39\% of the organizations surveyed agreed that REDD+ should reward large-scale businesses while another 39\% disagreed. Among those that disagreed were more than half of the national NGOs (57\%), all organizations representing indigenous and traditional communities, and more than $40 \%$ of state actors (Fig. 1). In contrast, $60 \%$ of donor representatives, $50 \%$ of national research institutions, and $50 \%$ of international NGOs agreed, as did most $(75 \%)$ of national business organizations (Fig. 1). The controversy of this issue stems, on the one hand, from the magnitude of the opportunity costs that large-scale actors will incur and, on the other, from concerns that large-scale actors will be rewarded for their poor prior environmental performance (Luttrell et al. 2013).

Fig. 1. Responses to the statement that REDD+ should reward large businesses for achieving emission reductions. Percentage measures by actors type.

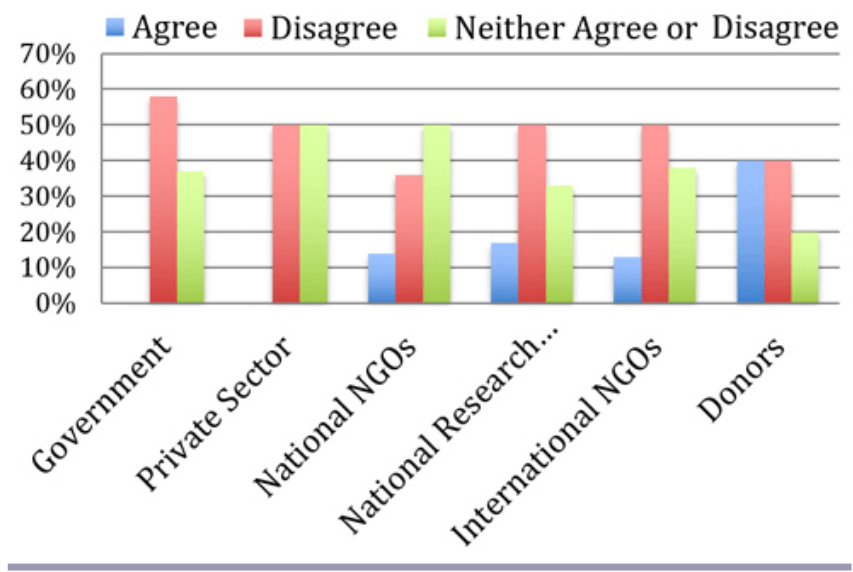

Interviewees were also divided over the statement about REDD+ and conflicts over land and forest resources. Overall, almost 40\% of all actors did not think that REDD+ would exacerbate land conflicts. Another 40\%, mainly domestic NGOs and some government agencies, thought that it could exacerbate such conflicts under certain circumstances, such as in the case of initiatives that did not involve the participation of affected actors. Those who disagreed included $50 \%$ of national businesses and $58 \%$ of government agencies (Fig. 2). Indigenous and traditional community representatives all agreed that REDD+ could exacerbate conflicts. 
Fig. 2. Responses to the statement that REDD+ projects will exacerbate conflicts over land and forest resources. Percentage measures by actors type.

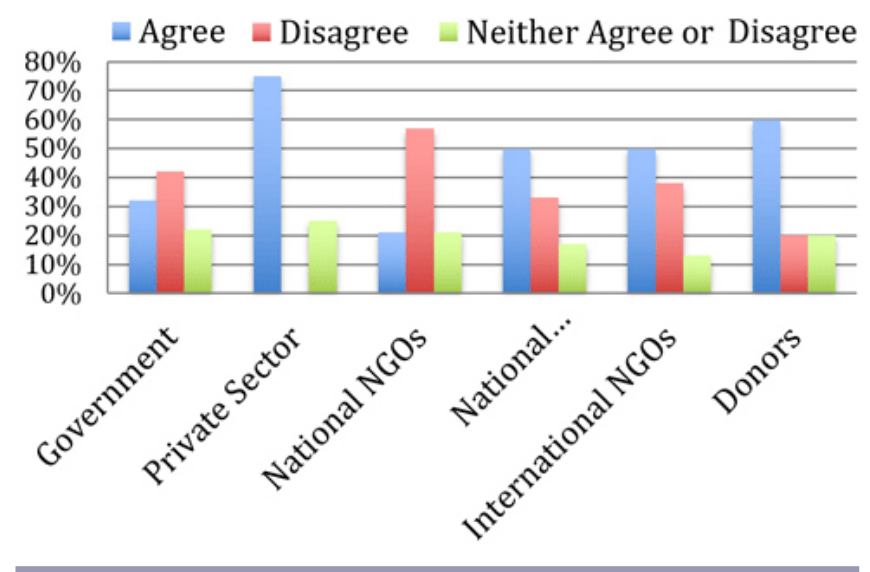

\section{Challenges for the national REDD+ strategy in Brazil}

Overall, the most significant challenges indicated by most actors were "the delay in the clarification of tenure rights" $(75 \%)$ and "achieving effective coordination between state agencies, the private sector, and civil society" $(55 \%)$. Challenges that provoked the least concern among actors included the risk of "social conflict and local resistance" $(39 \%)$ and "the lack of technical expertise for monitoring carbon emissions and sequestration" $(46 \%)$. Respondents considered several of the challenges suggested in the survey as representative of general challenges intrinsic to REDD+ implementation and therefore relevant not only to Brazil.

There was near consensus $(78 \%)$ on the principle of free, prior, and informed consent (FPIC) for "local forest users". However, private sector representatives challenged the definition of "local forest users" for two reasons: First, their understanding of "local forest users" included large private landowners and was not limited to smallholders or indigenous peoples; Second, in their view, illegal occupants or users of private or contested public lands should not have the right to consent or object to a REDD+ scheme, only legal landowners should be able to do so.

The results suggest that conceptual issues such as FPIC need to be part of the national REDD+ strategy in Brazil, and there is a need for the government to take a clearer position on the rights of each type of forest user. The lack of clarity surrounding specific REDD+ concepts reflects the slow progress of international REDD+ negotiations (see, for example, Kovacevic 2011). In addition, considering that the REDD+ approach in Brazil is mainly subnational at present, nesting these initiatives into a coherent national strategy will be a great challenge, especially given the vast differences between the legal Amazon and other biomes. According to one of the interviewees, "there will be issues for all initiatives and their promoters to get them 'nested' into the national system."

Furthermore, the lack of coordination between categories of actors (private sector, government, and civil society) suggests that $\mathrm{REDD}+$ governance in Brazil is fragile, which may undermine effective REDD+ policy making. In other words, no operational governance structures are in place beyond those involved in the series of consultations on strategy to facilitate interaction and coordination between the actors involved in decision making and thus to exploit desirable synergies among their specific capacities and competencies.

\section{Influence in policy networks: perspectives for REDD+ policy making}

The Amazon Environmental Research Institute (IPAM), a national NGO dedicated to environmental research and activism, emerged with the highest in-degree value in the influence network (41). This reveals its perceived influence in domestic REDD+ policies, as attested to by $75 \%$ of the organizations surveyed. Other organizations perceived as influential include: three government actors, namely the Ministry of Environment (MMA); the Office of the Presidential Chief of Staff (CS Office) and the National Institute for Space Research (INPE), a national scientific and technological organization linked to the Ministry of Science, Technology and Innovation (MCTI); and the Sustainable Amazonas Foundation (FAS), a national NGO tasked by Amazonas state law with implementing the Bolsa Floresta Program (Forest Allowance Program), a payment for ecosystem services program in the state of Amazonas (Table 1).

NGOs were recognized as relevant partners for sharing information on REDD+ matters (Table 1). The government sector appears to have more control over information exchange, as shown by the betweenness centrality of government actors in Table 1. The roles of MMA and Ministry of Foreign Relations (MRE) at the federal level earned them the highest in-degree and betweenness measures among government actors. At a regional level, two Amazon State Secretariats were perceived as important bridging actors for information exchanges. Among donors, GIZ (German Society for International Cooperation) presented high betweenness levels.

We observed that, in the information network, national NGOs were well connected with each other and occupied bridging positions in this network. In particular, we identified the National Council of Extractive Producers (CNS), Socio-Environmental Institute (ISA), and IPAM as the main brokers (Table 2). In the collaboration network, the bridging positions were occupied by ISA, the Institute for the Conservation and Sustainable Development of Amazonas (IDESAM), IPAM, and the Brazilian Forum for NGOs and Social Movements (FBOMS). However, we wondered whether this broker position reflected a coordination role that would support the expansion of collaboration among actors over time.

To investigate this, we measured the actors' brokerage indices through the total Gould and Fernandez (1989) brokerage measure in the directed information and collaboration networks. We used the "coordinator" and "liaison" broker indices (Table 2). The former indicates actors who have a mediating role in coordinating actors from the same actor category. The latter emphasizes actors who have a structural role on connecting actors from different sectors. In the information network, the potential coordination role was played by MRE, Sema-AC (State Environmental Secretariat of Acre), and MMA in the Government sector; and IPAM, FBOMS, ISA, CNS, and Climate Observatory (OC) in the NGO sector. Actors with a bridging role between actor 
Table 2. Brokerage measure of policy actors.

\begin{tabular}{|c|c|c|c|c|c|c|c|}
\hline \multirow{3}{*}{ Stakeholders } & \multirow{3}{*}{$\begin{array}{l}\text { Power and } \\
\text { Influence } \\
\text { REDD+ } \\
\text { national } \\
\text { strategy arenas }\end{array}$} & \multicolumn{6}{|c|}{ Actors influence - Brokerage } \\
\hline & & \multicolumn{3}{|c|}{ Communication network $^{\ddagger}$} & \multicolumn{3}{|c|}{ Collaboration network $^{\S}$} \\
\hline & & Betweenness & $\begin{array}{c}\text { Broker- } \\
\text { Coordinator }\end{array}$ & Broker-Liaison & Betweenness & $\begin{array}{c}\text { Broker- } \\
\text { Coordinator }\end{array}$ & Broker-Liaison \\
\hline \multicolumn{8}{|l|}{ Donors } \\
\hline FA & & 4 & 1 & 50 & 0 & 0 & 0 \\
\hline GIZ & & 8 & 6 & 93 & 6 & 0 & 4 \\
\hline World Bank & & 4 & 0 & 65 & 0 & 0 & 0 \\
\hline \multicolumn{8}{|l|}{ Government } \\
\hline MMA & $\begin{array}{l}\text { IWG, WG, STF, } \\
\text { PE }\end{array}$ & 6 & 12 & 43 & 3 & 0 & 2 \\
\hline CS Office & IWG, STF & 2 & 3 & 6 & 0 & 0 & 0 \\
\hline MCTI & IWG, STF & 1 & 3 & 3 & 0 & 0 & 0 \\
\hline MRE & IWG, STF & 11 & 57 & 38 & 0 & 0 & 0 \\
\hline SDS-AM & STF & 5 & 4 & 49 & 5 & 0 & 2 \\
\hline PPCDAM & & 3 & 10 & 34 & 0 & 0 & 0 \\
\hline Sema-AC & STF & 6 & 13 & 34 & 5 & 0 & 6 \\
\hline \multicolumn{8}{|l|}{ NGOs } \\
\hline IPAM & WG, PE, MC & 5 & 21 & 46 & 7 & 12 & 0 \\
\hline GTA & WG, MC & 1 & 7 & 0 & 1 & 4 & 0 \\
\hline ISA & WG, PE, MC & 6 & 17 & 57 & 15 & 8 & 8 \\
\hline $\mathrm{OC}$ & $\mathrm{MC}^{* *}$ & 3 & 14 & 14 & 2 & 0 & 0 \\
\hline IDESAM & WG, MC & 1 & 4 & 5 & 8 & 4 & 0 \\
\hline CNS & $\mathrm{MC}$ & 8 & 14 & 40 & 1 & 2 & 0 \\
\hline FBOMS & & 3 & 18 & 38 & 7 & 6 & 2 \\
\hline $\mathrm{TNC}$ & WG, PE, MC & 1 & 0 & 23 & 3 & 0 & 0 \\
\hline WWF & WG, MC & 4 & 0 & 73 & 0 & 0 & 0 \\
\hline \multicolumn{8}{|c|}{ Research Institutions } \\
\hline INPE & & 5 & 1 & 39 & 0 & 0 & 0 \\
\hline
\end{tabular}

CS Office: Office of the Presidential Chief of Staff; CNS: National Council of Extractive Producers; FA: Amazon Fund; FBOMS: Brazilian Forum for NGOs and Social Movements; GTA: Amazonian Working Group; GIZ: German Society for International Cooperation (formerly GTZ); IDESAM: Institute for the Conservation and Sustainable Development of Amazonas; INPE: National Institute for Space Research; IPAM: Amazon Environmental Research Institute; ISA: Socio-Environmental Institute; MCTI: Ministry of Science, Technology and Innovation; MMA: Ministry of Environment; MRE: Ministry of Foreign Relations; OC: Climate Observatory; PPCDAM: Action Plan for Prevention and Control of the Legal Amazon Deforestation; SDS-AM: State Sustainable Development Secretariat of Amazonas; Sema-AC: State Environmental Secretariat of Acre; TNC: The Nature Conservancy; WWF: World Wildlife Fund-Brazil;

${ }^{\dagger}$ Main arenas of power and influence on REDD+ national strategy: Interministerial Working Group on REDD+ (IWG), Working Groups (WG), States Task Force (STF), Panel of Experts (PE), and Multisectoral Committee (MC).

${ }^{\ddagger}$ Data related to undirected network, method symmetrize by maximum.

${ }^{\S}$ Data related to undirected network, only reciprocated ties.

the national strategy on REDD+ (Government of Brazil 2013) brings together all socio-environmental principles and criteria that were the result of consultations and work carried out by organized civil society (Bonfante et al. 2010), specifically, by the Multisectoral Committee.

We verified that IPAM and ISA, strong central actors in the policy network analysis, were represented on WGs to discuss the national strategy, as well as on the Panel of Experts and the Multisectoral Committee. We can see that their centered position in the networks and their structural influence were a reflection of the intense participation of these organizations in the process of discussion and elaboration of the national strategy. The prominence of IPAM and ISA in the networks, and their network measure scores reveal the coordination role they assumed among NGO actors.
NGOs can be seen as forming a coalition to influence the formulation of the national strategy. The numerous other actors from the NGO sector that appear as prominent in the networks analyzed substantiate these findings.

At the same time, among the 10 federal institutions that make up the Interministerial Working Group on REDD+, just two, MRE and MMA, have a potential coordinative role in the dialogue networks inside the government. However, the coordination score of MMA was lower than the MRE, which is surprising because MMA coordinated the WG dialogues, the Panel of Experts, and is leading the construction of the national strategy. When we consider their capacity to link different actor categories, only MMA plays this role in the information network, and no federal actors are central players as intermediaries or brokers in the 
collaboration network. This reflects the role assumed by MMA in leading the dialogue between the government and other sectors. The CS Office, which has formal institutional power on the Interministerial Committee on Climate Change, is perceived as an influential actor by others, but it does not seem to develop the coordination role of the other federal actors or link different sectors on REDD+ issues.

The absence of coordination between different types of actors (private sector, government, and civil society) suggests that national REDD+ governance in Brazil is unlikely to be optimal. In addition, cross-scale interaction is a key requirement for effective REDD+ implementation (Korhonen-Kurki et al. 2012). Nevertheless we show that some actors, because of their liaison brokerage position, have a potential role in coordinating actions to achieve effective REDD+ implementation. The controversy over whether to reward large industries for emission reductions, which is related to benefits sharing, reflects the emerging political economy of REDD+ and the power relations embedded within it. The draft of the national strategy under review for public consultation notes the importance of including large industries in schemes for REDD+ benefits sharing by pointing out the significant resources they generate through environmental compensations (Government of Brazil 2013). However, the types of incentives (or disincentives) that could be applied to mobilize these actors remain undefined, suggesting that the controversy is not yet resolved.

Interviews revealed that tenure clarification is among the main challenges for the national strategy. The text under construction does not refer explicitly to this subject, showing that this concern often expressed by actors is not yet reflected in the national strategy. The text, on the other hand, recognizes that REDD+ governance is still fragile in Brazil. It thus proposes that the bulk of resources be invested in increasing institutional capacity and strengthening governance, although specific actions have yet to be identified and budgeted.

Important networks and influential actors have been identified in the REDD+ policy arena. National NGOs and government agencies are the most influential REDD+ policy-making actors in Brazil. IPAM and ISA, for example, have been working on REDD+-related issues since 2000 (see, for example, Santilli et al. 2005). ISA emerged from the survey as the principal broker in network governance of REDD+. ISA and IPAM were able to influence the UNFCCC negotiations in 2003, through the "compensated reduction" proposal for reducing emissions from deforestation, and they have been engaging a range of local actors in the debate since then (see, for example, IPAM 2008). ISA is among the most connected organizations in the information and collaboration networks and is one of the main brokers that links different categories of actors. IPAM also takes a lead in the information and collaboration networks, used here to gauge longterm governance, but its main role is to connect actors of the same category.

If local actors are not engaged in the debate of the national strategy from the outset, a fully participatory strategy for REDD+ may not arise in critical localities and benefits may not be equitably shared among stakeholders (Griffiths 2008, Costenbader 2010). The reason for this is that equitable benefitsharing depends on the degree of local participation in the process of developing and implementing REDD+ benefits (Gebara 2013, Luttrell et al. 2013). For example, as the results show, it might not be possible to fully implement FPIC in Brazil because traditional and low-income communities are often marginalized by decisions over land use and infrastructure developments. In this sense, agreement on the importance of principles associated with REDD+ in the national strategy, such as FPIC, may be necessary but not sufficient to lead to the desired policy outcomes. At the moment, the participation of local actors is referred to in the strategy as a safeguard, as a result of the work of the Multisectoral Committee, organized by civil society. However, how FPIC will be implemented in practice, is not clear from the draft strategy.

Among government agencies, influential actors include the MRE and the MMA. These two actors are prominent as brokers in the information network, but their main role is to coordinate actors in the government sector. Such actors could potentially exert control over others in the network because of their privileged structural position in exchanging information. This control may serve as a constraint for REDD+ policy making and implementation in Brazil, because the flow of information among actors and groups is essential for the development of governance structures that facilitate knowledge sharing and coordination, which are critical for REDD+ (Brockhaus and Angelsen 2012).

Furthermore, the private sector's lack of involvement has serious implications for the effectiveness of REDD+. For example, the substantial resources that the private sector could mobilize are unclear in the national strategy under construction, as are commitments to make agribusiness and territorial expansion more sensitive to rainforest conservation (see, for example, Di Gregorio et al. 2012). Considering that large-scale private businesses are among the principal actors not only driving deforestation and forest degradation but also influencing politics in Brazil (May et al. 2011a, Hargrave and Kis-Katos 2013), these drivers might not be effectively addressed during the policy design stage. One option for involving the private sector in REDD+ policy making in Brazil would be to promote public-private partnerships and collaborations that would include national REDD+ safeguards, as required by the Cancun Agreements (UNFCCC 2010).

Finally, we observed that each group of actors has its own agenda with regard to its role in REDD+: environmental NGOs are focused on the reduction of deforestation and improved biodiversity conservation; organizations of indigenous people and traditional communities prioritize their rights to land and forest resources and REDD+ benefit sharing; and agribusinesses are taking a very precautionary and risk-averse stance toward REDD+, emphasizing the legal rights and opportunity costs of using private land in accordance with market demands, while seeking financial benefits from REDD+. As a result, the present sectoral analysis questions the likelihood of achieving an integrated national agenda on REDD+ that enjoys agreement among all principal policy actors. Failure in this regard may jeopardize the effectiveness of the national strategy in terms both of emission reductions and of other desirable socioenvironmental outcomes.

\section{CONCLUSION}

In the Brazilian context, the optimistic and widespread view that REDD+ will be effective in reducing emissions from deforestation 
suggests a promising context for the advance of REDD+ policy making. However, the existence of polarization among some actor stances warns of the need to create an environment that supports negotiation among all sectors. Such cross-sectoral governance is essential if REDD+ policy is to move forward effectively (Cash et al. 2006, Brondizio et al. 2009). In particular, the government and national NGOs wield considerable influence in the REDD+ arena. International donors and NGOs have a significant role in connecting sectors, which confirms that they too are able to influence policy directions.

The governance actors studied here all appear to be potentially influential in the long term because they serve as mediators in the information and collaboration networks; in performing this function, they can gain experience in management and governance, which could stimulate the formation of strong coalitions and influence governance directions in the future (Marsh and Rhodes 1992). If influential actors would cooperate more willingly, e.g., through involvement of industry as well as indigenous peoples and local communities, implementation would likely reflect better the core aims of REDD+: emission reductions and protection of safeguards. By contrast, a lack of coordination among actors can function as a constraint in this process.

The analysis indicates that REDD+ policy making and implementation is neither straightforward nor fluid, and in some situations, trade-offs among aims might be inevitable. If so, REDD+ may not be a "win-win" strategy, as was widely hoped when the scheme was conceived. Those designing and implementing REDD+ policies will need to be clear about the priority they assign to each environmental and socioeconomic objective. The extremely complex task of stopping deforestation involves a multitude of actors and a variety of governance approaches. As seen, although participatory design of a national strategy has advanced, Brazil still lacks many key elements, including an essential role for the private sector.

Responses to this article can be read online at: http://www.ecologyandsociety.org/issues/responses. $\mathrm{php} / 6744$

\section{Acknowledgments:}

This research forms part of the policy component of CIFOR's Global Comparative Study on REDD+ (http://www.forestsclimatechange. org/global-comparative-study-on-redd.html). The methods applied in this study build partially on research undertaken by the Comparing Climate Change Policy Networks program (http:// compon.org), funded by the National Science Foundation. We thank Christine Wairata, Sofi Mardiah, Efrian Muharrom, Catarina Freitas, and CIFOR's communications team, who made valuable contributions in research support and editing. Funding for CIFOR's research was provided by the Norwegian Agency for Development Cooperation, the Australian Agency for International Development, the UK Department for International Development, and the European Commission.

\section{LITERATURE CITED}

Agrawal, A., D. G. Brown, G. Rao, R. Riolo, D. T. Robinson and M. Bommarito II. 2012. Interactions between organizations and networks in common-pool resource governance. Environmental Science \& Policy 25:138-146. http://dx.doi.org/10.1016/j. envsci.2012.08.004

Angelsen, A., M. Brockhaus, M. Kanninen, E. Sills, W. Sunderlin, and S. Wertz-Kanounnikoff, editors. 2009. Realising REDD+. national strategy and policy options. CIFOR, Borgor, Indonesia.

Assunção, J., C. Gandour, R. Rocha, and R. Rocha. 2013. Does credit affect deforestation? Evidence from a rural credit policy in the Brazilian Amazon. Technical Report, Climate Policy Initiative, Rio de Janeiro, Brazil. [online] URL: http://climatepolicyinitiative. org/wp-content/uploads/2013/01/Does-Credit-Affect-DeforestationEvidence-from-a-Rural-Credit-Policy-in-the-Brazilian-AmazonTechnical-Paper-English.pdf

Berkes, F. 2006. From community-based resource management to complex systems: the scale issue and marine commons. Ecology and Society 11(1): 45. [online] URL: http:/www.ecologyandsociety. org/vol11/iss1/art45/

Besussi, E. 2006. Policy networks: conceptual developments and their European applications. Working Paper Series Paper 102. Centre for advanced spatial analysis, University College London, London, UK.

Bodin, Ö., and B. Crona. 2009. The role of social networks in natural resource governance: what relational patterns make a difference? Global Environmental Change 19:366-374. http://dx. doi.org/10.1016/j.gloenvcha.2009.05.002

Bodin, Ö., B. Crona, and H. Ernstson. 2006. Social networks in natural resource management: What is there to learn from a structural perspective? Ecology and Society 11(2): r2. [online] URL: http://www.ecologyandsociety.org/vol11/iss2/resp2/

Bodin, Ö., and C. Prell, editors. 2011. Social networks and natural resource management: uncovering the social fabric of environmental governance. Cambridge University Press, Cambridge, UK. http:// dx.doi.org/10.1017/CBO9780511894985

Bonfante, T. M., M. Voivodic, and L. Meneses Filho. 2010. Desenvolvendo Salvaguardas Socioambientais de REDD+: um guia para processos de construção coletiva. Imaflora, Piracicaba, SP, Brazil. 40 p.

Borgatti, S. P., M. G. Everett, and L. C. Freeman. 2002. UCINET for Windows: software for social network analysis. Analytic Technologies, Harvard, Massachusetts, USA. [online] URL: https://sites.google.com/site/ucinetsoftware/home

Börzel, T. A. 1998. Organizing Babylon: on the different conceptions of policy networks. Public Administration 76 (2):253-273. http://dx.doi.org/10.1111/1467-9299.00100

Börzel, T. A., and K. Heard-Lauréote. 2009. Networks in EU multi-level governance: concepts and contributions. Journal of Public Policy 29(2):135-151. http://dx.doi.org/10.1017/ $\underline{\mathrm{S} 0143814 \mathrm{X} 09001044}$

Brockhaus, M., and A. Angelsen. 2012. Seeing REDD+ through 4Is. A political economy framework. Pages 15-30 in A. Angelsen, M. Brockhaus, W. Sunderlin, and L. Verchot, editors. Analysing 
REDD+: challenges and choices. Center for International Forestry Research, Bogor, Indonesia.

Brockhaus, M., and M. Di Gregorio. 2012. A brief overview: component 1 on national REDD+ policies and processes. CIFOR Infobrief 13. Center for International Forestry Research, Bogor, Indonesia.

Brockhaus, M., M. Di Gregorio, and S. Mardiah. 2013. Governing the design of national REDD+: an analysis of the power of agency. Forest Policy and Economics. In press. http://dx. doi.org/10.1016/j.forpol.2013.07.003

Brondizio, E. S., E. Ostrom, and O. R. Young. 2009. Connectivity and the governance of multilevel social-ecological systems: the role of social capital. Annual Review of Environment and Resources 34:253-278. http://dx.doi.org/10.1146/annurev.environ.020708.100707

Burt, R. S. 2005. Brokerage and closure: an introduction to social capital. Oxford University Press, Oxford, UK.

Carlsson, L. 2000. Policy networks as collective action. Policy Studies Jornal 28(3):502-520. http://dx.doi.org/10.1111/j.1541-0072.2000. $\underline{\text { tb02045.x }}$

Cash, D. W., W. N. Adger, F. Berkes, P. Garden, L. Lebel, P. Olsson, L. Pritchard, and O. Young. 2006. Scale and cross-scale dynamics: governance and information in a multilevel world. Ecology and Society 11(2): 8. [online] URL: http://www.ecologyandsociety. org/vol11/iss $2 / \operatorname{art} 8 /$

Costenbader, J. 2010. REDD+ benefit sharing: a comparative assessment of three national policy approaches. International Union for Conservation of Nature, Gland, Switzerland.

Crona, B., H. Ernstson, C. Prell, M. Reed, and K. Hubacek. 2011. Combining social network approaches with social theories to improve understanding of natural resource governance. Pages 44-72 in Ö. Bodin and C. Prell, editors. Social networks and natural resource management: uncovering the social fabric of environmental governance. Cambridge University Press, Cambridge, UK. http:// dx.doi.org/10.1017/CBO9780511894985.004

Cronkleton, P., D. B. Bray, and G. Medina. 2011. Community forest management and the emergence of multi-scale governance institutions: lessons for REDD+ development from Mexico, Brazil and Bolivia. Forests 2(2):451-473. http://dx.doi. org/10.3390/f2020451

Cumming, G. S., Ö. Bodin, H. Ernston, and T. Elmqvist. 2010. Network analysis in conservation biogeography: challenges and opportunities. Diversity and Distributions 16:414-425. http://dx. doi.org/10.1111/j.1472-4642.2010.00651.X

Dassen, A. 2010. Networks: structure and action: steering in and steering by policy networks. Thesis. Twente University, Enschede, Netherlands. http://dx.doi.org/10.3990/1.9789036529624

Di Gregorio, M., M. Brockhaus, T. Cronin, and E. Muharrom. 2012. Politics and power in national REDD+ policy processes. Pages 69-90 in A. Angelsen, M. Brockhaus, W. Sunderlin, and L. Verchot, editors. Analysing REDD+: challenges and choices. Center for International Forestry Research, Bogor, Indonesia.

Diani, M. 2003 "Leaders" or brokers? Positions and influence in social movement networks. Pages 105-122 in M. Diani, and D.
McAdam, editors. Social movements and networks: relational approaches to collective action. Oxford University Press, Oxford, UK.

Dietz, T., E. Ostrom, and P. C. Stern. 2003. The struggle to govern the commons. Science 302(5652):1907-1912. http://dx.doi. org/10.1126/science.1091015

Eliasch, J. 2008. Climate change: financing global forests: the Eliasch review. Office of Climate Change, London, UK. [online] URL: http://www.official-documents.gov.uk/document/ other/9780108507632/9780108507632.pdf

Ernstson, H. 2011. Transformative collective action: a network approach to transformative change in ecosystem-based management. Pages 255-287 in Ö. Bodin and C. Prell, editors. Social networks and natural resource management: uncovering the social fabric of environmental governance. Cambridge University Press, Cambridge, UK. http://dx.doi.org/10.1017/CBO9780511894985.012

Fawcett, P., and C. Daugbjerg. 2012. Explaining governance outcomes: epistemology, network governance and policy network analysis. Political Studies Review 10(2):195-207. http://dx.doi. org/10.1111/j.1478-9302.2012.00257.x

Fischer, M., A. Fischer, and P. Sciarini. 2009. Power and conflict in the Swiss political elite: an aggregation of existing network analyses. Swiss Political Science Review 15(1):31-62. http://dx.doi. org/10.1002/j.1662-6370.2009.tb00122.x

Freeman, L. C. 1979. Centrality in social networks conceptual clarification. Social Networks 1(3):215-239. http://dx.doi. org/10.1016/0378-8733(78)90021-7

Gebara, M. F. 2011. REDD+ institutions: a preliminary analysis. Pages 161-176 in C. C. Oliveira and R. S. Rocha Sampaio, editors. A economia do verde no contexto do desenvolvimento sustentável: a governança dos atores públicos e privados. Fundação Getulio Vargas (FGV) Direito Rio, Rio de Janeiro, Brazil.

Gebara, M. F. 2013. Importance of local participation in achieving equity in benefit-sharing mechanisms for REDD+: a case study from the Juma Sustainable Development Reserve. International Journal of the Commons 7(2). [online] URL: http:// www.thecommonsjournal.org/index.php/ijc/article/view/301/328

Gebara, M. F., P. May, R. S. Rocha Sampaio, and A. Thuault. 2012. REDD+ initiatives in Brazil: how are global climate accords reflected on the ground? Pages 25-42 in J. Similä and E. Primmer, editors. Legal analysis of the relationship between WTO law, European state aid and nature conservation law, and economic instruments for biodiversity protection. POLICYMIX Report, Issue 7/2012. [online] URL: http://policymix.nina.no/Portals/ policymix/Documents/POLICYMIX\%20Report $\% 207$ 2012.pdf

Gould, R. V., and R. M. Fernandez. 1989. Structures of mediation: a formal approach to brokerage in transactions networks. Sociological Methodology 19:89-126. http://dx.doi. org/10.2307/270949

Government of Brazil. 2013. Estratégia Nacional de REDD+ do Brasil. Versão Preliminar. Comitê Interministerial de Mudança do Clima (CIM), Grupo Executivo sobre Mudanças Climáticas (GEx) and Grupo de Trabalho Interministerial sobre REDD+ (GT REDD+). Brasília, DF, Brazil. 
Griffiths, T. 2008. Seeing "REDD”? Forests, climate change mitigation and the rights of indigenous peoples and local communities. Forest Peoples Programme, Moreton-in-Marsh, UK.

Hanneman, R. A. M., and M. Riddle. 2005. Introduction to social network methods. University of California, Riverside, California, USA. [online] URL: http://faculty.ucr.edu/ hanneman/nettext/

Hargrave, J., and K. Kis-Katos. 2013. Economic causes of deforestation in the Brazilian Amazon: a panel data analysis for the 2000s. Environmental Resource Economics 54:471-494. http:// dx.doi.org/10.1007/s10640-012-9610-2

Instituto de Pesquisa Ambiental da Amazonia (IPAM). 2008. Declaração de Manaus. IPAM, Brasilia, Brazil. [online] URL: http://www.ipam.org.br/biblioteca/livro/Declaracao-de-Manaus/92

Intergovernmental Panel on Climate Change (IPCC). 2007. Climate change 2007: synthesis report summary for policymakers. Fourth assessment report. Cambridge University Press, Cambridge, UK.

Janssen, M. A., Ö. Bodin, J. M. Anderies, T. Elmqvist, H. Ernstson, R. R. J. McAllister, P. Olsson, and P. Ryan. 2006. Toward a network perspective of the study of resilience in socialecological systems. Ecology and Society 11(1): 15. [online] URL: http://www.ecologyandsociety.org/vol11/iss1/art15/

Knoke, D., and S. Yang. 2008. Social network analysis. Quantitative Applications in the Social Sciences Series 154. 2nd edition. Sage, Thousand Oaks, California, USA.

Korhonen-Kurki, K., M. Brockhaus, A. Duchelle, S. Atmadja, and T. T. Pham. 2012. Multiple levels and multiple challenges for REDD+. Pages 91-110 in A. Angelsen, M. Brockhaus, W. Sunderlin and L. Verchot, editors. Analysing REDD+: challenges and choices. Center for International Forestry Research, Bogor, Indonesia.

Kovacevic, M. 2011. Durban talks both good and bad for REDD+, says expert. Forests News: a Blog by the Center for International Forestry Research, 14 December. [online] URL: http://blog.cifor.org/6507/durban-talks-both-good-and-bad-for-reddsays-expert/\#.UbWGpvZgbpA

Kriesi, H., S. Adam, and M. Jochum. 2006. Comparative analysis of policy networks in Western Europe. Journal of European Public Policy 13(3):341-361. http://dx.doi.org/10.1080/13501760500528803

Luttrell, C., L. Loft, M. F. Gebara, D. Kweka, M. Brockhaus, A. Angelsen, and W. D. Sunderlin. 2013. Who should benefit from REDD+? Rationales and realities. Ecology and Society 18(4): 52. http://dx.doi.org/10.5751/ES-05834-180452

Marsh, D., and R. A. W. Rhodes, editors. 1992. Policy networks in British government. Clarendon Press, Oxford, UK. http://dx. doi.org/10.1093/acprof:oso/9780198278528.001.0001

May, P. H., B. Calixto, and M. F. Gebara. 2011b. REDD+ politics in the media: a case study from Brazil. Working paper 55. Center for International Forestry Research, Bogor, Indonesia.

May, P. H., B. Millikan, and M. F. Gebara. 2011a. The context of REDD+ in Brazil: drivers, agents and institutions. Occasional paper 55, revised edition. Center for International Forestry Research, Bogor, Indonesia.
Ministério do Meio Ambiente (MMA). 2012. REDD+: Relatório de Painel Técnico do MMA sobre financiamento, benefícios e cobenefícios. MMA, Brasília, DF, Brazil. [online] URL: http:// www.conservation.org. br/arquivos/redd+ relatorio de painel tecnico do mma sobre financiamento beneficios e cobeneficios. pdf

Newig, J., D. Günther, and C. Pahl-Wostl. 2010. Synapses in the network: learning in governance networks in the context of environmental management. Ecology and Society 15(4): 24. [online] URL: http://www.ecologyandsociety.org/vol15/iss4/ $\underline{\operatorname{art} 24 /}$

Newman, L., and A. Dale. 2005. The role of agency in sustainable local community development. Local Environment 10(5):477-486. http://dx.doi.org/10.1080/13549830500203121

Ostrom, E. 2009. A general framework for analyzing sustainability of social-ecological systems. Science 325 (5939):419-422. http://dx.doi.org/10.1126/science.1172133

Prell, C. 2011. Some basic structural characteristics of networks. Pages 29-43 in Ö. Bodin and C. Prell, editors. Social networks and natural resource management: uncovering the social fabric of environmental governance. Cambridge University Press, Cambridge, UK. http://dx.doi.org/10.1017/CBO9780511894985.003

Prell, C., K. Hubacek, and M. Reed. 2009. Stakeholder analysis and social network analysis in natural resource management. Society and Natural Resources 22(6):501-518. http://dx.doi. org/10.1080/08941920802199202

Reed, M. S., A. Graves, N. Dandy, H. Posthumus, K. Hubacek, J. Morris, C. Prell, C. H. Quinn, and L. C. Stringer. 2009. Who's in and why? A typology of stakeholder analysis methods for natural resource management. Journal of Environmental Management 90(5):1933-1949. http://dx.doi.org/10.1016/j. jenvman.2009.01.001

Rhodes, R. A. W. 1997. Understanding governance: policy networks, governance, reflexivity and accountability. Open University Press, Buckingham, UK.

Sabatier, P. A., and H. C. Jenkens-Smith. 1993. Policy change and learning: an advocacy coalition approach. Westview Press, Boulder, Colorado, USA.

Sandström, A. 2011. Social networks, joint image building, and adaptability: the case of local fishery management. Pages 288-321 in Ö. Bodin and C. Prell, editors. Social networks and natural resource management: uncovering the social fabric of environmental governance. Cambridge University Press, Cambridge, UK. http:// dx.doi.org/10.1017/CBO9780511894985.013

Santilli, M., P. Moutinho, S. Schwartzman, D. Nepstad, L. Curran and C. Nobre. 2005. Tropical deforestation and the Kyoto Protocol. Climatic Change 71(3):267-276 http://dx.doi.org/10.1007/ s10584-005-8074-6

Scott, J. 2000. Social network analysis: a handbook. Sage, London, UK.

Stern, N. 2007. The economics of climate change: the Stern review. Cambridge University Press, Cambridge, UK. http://dx.doi. org/10.1017/CBO9780511817434 
Thorelli, H. B. 1986. Networks: between markets and hierarchies. Strategic Management Journal 7(1):37-51. http://dx.doi. org/10.1002/smj.4250070105

United Nations Framework Convention on Climate Change (UNFCCC). 2007. Decision-/CP.13 Bali Action Plan. UNFCCC, Bali, Indonesia. [online] URL: http://unfccc.int/files/meetings/ cop 13/application/pdf/cp bali action.pdf

United Nations Framework Convention on Climate Change (UNFCCC). 2010. Outcome of the work of the Ad Hoc Working Group on Long-term Cooperative Action under the Convention. Cancun Agreements, FCCC/CP/2010/7/Add. 1. Decision 1/CP. 16. UNFCCC, Cancun, Mexico. [online] URL: https://unfccc.int/ files/meetings/cop_16/application/pdf/cop16_lca.pdf

Wasserman, S., and K. Faust. 1994. Social network analysis: methods and applications. Cambridge University Press, Cambridge, UK. http://dx.doi.org/10.1017/CBO9780511815478 
Appendix 1- List of Organizations Surveyed

\begin{tabular}{|c|c|}
\hline $\begin{array}{l}\text { Acronym } \\
\text { (Portuguese) }\end{array}$ & Full name (English) \\
\hline \multicolumn{2}{|c|}{ Government, state agencies and expressly political organizations } \\
\hline $\mathrm{CC} / \mathrm{Pr}$. & Executive Office (Casa Civil) of the Presidency of the Republic \\
\hline SDS-AM & $\begin{array}{l}\text { State Secretariat of Environment and Sustainable Development - } \\
\text { Amazonas }\end{array}$ \\
\hline MCTI & $\begin{array}{l}\text { Ministry of Science,Technology and Innovation - Division of Global } \\
\text { Climate Change }\end{array}$ \\
\hline CONAFLOR & National Commission on Forests \\
\hline CONAMA & National Council of the Environment \\
\hline MRE & $\begin{array}{l}\text { Ministry of Foreign Relations - Division of Environmental Policies } \\
\text { and Sustainable Development }\end{array}$ \\
\hline MMA & Ministry of Environment - Climate Change Secretariat \\
\hline $\begin{array}{l}\text { Dep.Garcia/ } \\
\text { Câmara }\end{array}$ & Congresswoman Rebecca Garcia, National Chamber of Deputies \\
\hline FGAL & Forum of Governors of the Legal Amazon region \\
\hline FUNAI & National Indian Foundation \\
\hline $\begin{array}{l}\text { PPCDAM/ } \\
\text { MMA }\end{array}$ & $\begin{array}{l}\text { Interministrial Working Group for the Action Plan for the Prevention } \\
\text { and Control of Deforestation in the Legal Amazon }\end{array}$ \\
\hline IBAMA & $\begin{array}{l}\text { Brazilian Institute of Environmental Protection and Renewable Natural } \\
\text { Resources }\end{array}$ \\
\hline INPA & National Institute of Amazon Research \\
\hline INPE & $\begin{array}{l}\text { National Institute of Space Research, Ministry of Science and } \\
\text { Technology }\end{array}$ \\
\hline IPEA & $\begin{array}{l}\text { Institute of Applied Economic Research, Secretary of Strategic } \\
\text { Affairs, Presidency of the Republic }\end{array}$ \\
\hline MAPA & Ministry of Agriculture, Livestock and Food Supply \\
\hline $\mathrm{SAE} / \mathrm{Pr}$. & Secretariat of Strategic Affairs, Presidency of the Republic \\
\hline SEMA-AC & State Secretariat of Environment - Acre \\
\hline SEMA-MT & State Secretariat of Environment - Mato Grosso \\
\hline SFB & Brazilian Forestry Service \\
\hline SPE/MF & Secretariat of Economic Policy, Ministry of the Economy \\
\hline Petrobras & Brazilian Petroleum Corporation \\
\hline EMBRAPA & Brazilian Enterprise for Agricultural and Livestock Research \\
\hline National Res & h Institutes \\
\hline
\end{tabular}




\begin{tabular}{|c|c|}
\hline FGV/Ces & Getúlio Vargas Foundation - Center for Sustainability Studies \\
\hline UFMG & Federal University of Minas Gerais \\
\hline \multicolumn{2}{|c|}{ National Business Organizations } \\
\hline ABAG & Brazilian Association of Agribusiness \\
\hline ABEMC & Brazilian Association of Carbon Market Enterprises \\
\hline ABIOVE & Brazilian Association of Vegetal Oil Industries \\
\hline ABRAF & Brazilian Association of Planted Forest Producers \\
\hline CEBDS & The Brazilian Business Council for Sustainable Development \\
\hline CNA & National Confederation of Agriculture and Livestock \\
\hline FIESP & $\begin{array}{l}\text { Federation of Industries of the State of São Paulo - Superior Council } \\
\text { of Agribusiness }\end{array}$ \\
\hline ABTCP & Brazilian Technical Association for Cellulose and Paper \\
\hline \multicolumn{2}{|c|}{ Environmental NGOs } \\
\hline FAS & Sustainable Amazonas Foundation \\
\hline FBMC & Brazilian Forum on Climate Change \\
\hline FUNBIO & Brazilian National Biodiversity Fund \\
\hline $\mathrm{ICV}$ & Institute Center of Life \\
\hline IDESAM & Institute of Conservation and Sustainable Development of Amazonas \\
\hline IMAFLORA & Institute for Agricultural and Forest Management and Certification \\
\hline IMAZON & Amazon Institute of People and the Environment \\
\hline IPAM & Institute of Environmental Research of the Amazon \\
\hline ISA & Socio-Environmental Institute \\
\hline $\mathrm{OC}$ & Climate Observatory \\
\hline SPVS & Society of Wildlife Research and Environmental Education \\
\hline $\mathrm{CNS}$ & National Council of Rubber Tappers \\
\hline COIAB & Coordination of Indigenous Organizations of the Brazilian Amazon \\
\hline FBOMS & Brazilian Forum of Social Movements and NGOs \\
\hline GTA & The Amazonian Working Group \\
\hline Vitae Civilis & Vitae Civilis Institute \\
\hline \multicolumn{2}{|c|}{ International NGOs } \\
\hline AdT & Friends of the Earth-Brazilian Amazon \\
\hline CI-Brasil & Conservation International \\
\hline CIFOR & Center for International Forestry Research \\
\hline EDF-EUA & Environmental Defense Fund \\
\hline Greenpeace & Greenpeace \\
\hline TNC-Brasil & The Nature Conservancy \\
\hline WWF-Brasil & World Wildlife Fund \\
\hline COICA & Coordination of Indigenous Organizations of the Amazon Basin \\
\hline
\end{tabular}




\begin{tabular}{|l|l|}
\hline GCF & Governors' Climate and Forests Task Force \\
\hline Donors & World Bank \\
\hline WB & Global Environment Facility \\
\hline GEF & Climate and Land Use Alliance \\
\hline CLUA & $\begin{array}{l}\text { German Institute for Technical Cooperation, German Federal } \\
\text { Government }\end{array}$ \\
\hline GIZ & Norwegian Embassy in Brazil, Government of Norway \\
\hline Norway & National Fund for Forest Development \\
\hline FNDF & Amazon Fund, National Bank of Economic and Social Development \\
\hline FA/BNDES
\end{tabular}

